\title{
Effect of Feeding Dried Orange Pulp to Lactating Dairy Cows on Nutrients Digestibility, Blood Constituents, Plasma Antioxidant Biomarker, and Pathogenic Fecal Bacteria
}

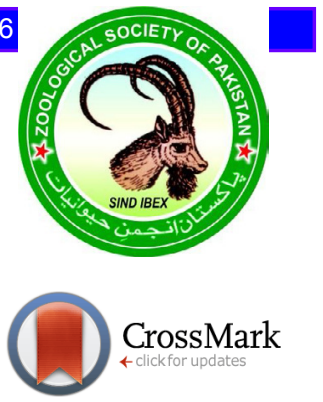

\author{
Sabbah M. Allam, T.M. El-Bedawy, M.H. Bakr and A.E.M. Mahmoud* \\ Animal Production Department, Faculty of Agriculture, Cairo University, Giza, Egypt
}

\begin{abstract}
A B S T RA C T
Experiments were conducted to study the effect of using dried orange pulp (DOP), as an alternative energy source in the ration of Holstein dairy cows, on nutrient digestibility, blood constituents, level of antioxidants in plasma, and presence and count of fecal pathogenic bacteria e.g. E. coli and Salmonella spp. Forty lactating Holstein cows, weighing $550 \pm 50 \mathrm{~kg}$, with an average of $20 \mathrm{~kg}$ daily milk yield, were randomly divided into four groups (ten in each group). Animals were fed rations containing DOP at 0 , 25,50 and $75 \%$ substitution of yellow corn grains (R1, R2, R3 and R4, respectively). Digestion trail was conducted in the last week of the experiment using Acid Insoluble Ash method. Feces samples were taken and analyzed in the same day for Salmonella spp. and E. coli and blood samples for analysis were taken from the subcutaneous abdominal vein. The experimental rations were almost identical in chemical composition. Results of nutrient digestibility and nutritive value, as total digestible nutrients (TDN) and digestible crude protein, showed that there were insignificant $(\mathrm{P}>0.05)$ differences between cows fed $\mathrm{R} 2$, R3 and R4 compared with those fed R1 (control), except digestibility of nitrogen free extract which was significantly $(\mathrm{P} \leq 0.05)$ decreased by feeding experimental rations by increasing replacement level of DOP to more than $25 \%$ (R2). Blood constituents of experimental cows on all rations were within normal range for platelets, red blood cells (RBCs), hematocrit, hemoglobin ( $\mathrm{Hb}, \mathrm{g} / \mathrm{dl}$ ), alanine transaminase (ALT), aspartate transaminase (AST), total protein $(\mathrm{g} / \mathrm{dl})$, albumin $(\mathrm{g} / \mathrm{dl})$, creatinine $(\mathrm{mg} / \mathrm{dl})$ and urea. However, white blood cells (WBCs), globulin and total lipids were significantly $(\mathrm{P} \leq 0.05)$ decreased by increasing the replacement level of DOP. Total lipids values decreased by increasing the replacement levels of DOP more than $25 \%$ (R2) and total antioxidant capacity (TAC) in blood plasma, regarded as a biomarker of oxidative stress in cows, was insignificantly $(\mathrm{P}>0.05)$ affected by feeding experimental rations and ranged from 0.420 to $0.433 \mathrm{~mm} / 1$. Salmonella spp. was not detected and $E$. coli was insignificantly $(\mathrm{P}>0.05)$ affected by feeding DOP rations. It could be concluded that DOP can be used as an alternative source of energy in Holstein dairy cow's rations, replacing up to $75 \%$ of yellow corn grains without negatively effecting nutrient digestibility, nutritive values, as TDN or digestible $\mathrm{CP}$, and without showing any harmful effect on animal health. More studies are needed to examine the effect of citrus by-products on presence of fecal E. coli and Salmonella species, and on antioxidant biomarkers.
\end{abstract}

Article Information
Received 03 September 2017
Revised 22 May 2018
Accepted 13 February 2019
Available online 03 October 2019
Authors' Contribution
SMA presented the idea and wrote the
article. TME and AEMM statistically
analysed the data and revised
the article. MHB performed the
experiments and analysed the data.
Key words
Dairy cattle, Dried orange pulp,
Corn grains, Digestibility, Blood
constituents, Plasma antioxidant,
Fecal pathogenic bacteria.

\section{INTRODUCTION}

$\mathrm{C}$ orn grains represent a high percentage of concentrates for ruminants, causing an increase in prices of concentrate feeds. This represents a challenge to animal nutritionists to search for alternative feedstuffs, or agroindustrial by-products that may replace corn grains as a cheaper source of energy in animal rations.

Dried citrus pulp (DCP) is widely used in feeding dairy cows. The dried citrus pulp is a by-product produced after extraction of juice from citrus fruits and drying of the residues. It is classified as an energy concentrate by-product feed. The DCP includes a mixture of peel,

\footnotetext{
* Corresponding author: akkb2010@gmail.com 0030-9923/2020/0079-0001 \$ 9.00/0

Copyright 2020 Zoological Society of Pakistan
}

inside portions, and culled fruits of the citrus family (e.g., orange, lemons, and grapefruit, etc.) that has been dried to produce a coarse, flakey product (Harris, 1991). Source of fruit and method of processing may be considered the main factors that affect the nutrient content of DCP (Ammerman and Henry, 1991).

For sustained and reliable use of non-traditional feedstuffs in animal feed systems, the quantities produced annually and also availability of those feedstuffs must be known. Most of the citrus fruits grown worldwide consist of oranges of various verieties (Hutton, 1987). In 2013/2014, annual world production of oranges was estimated at 50.7 million metric tons (USDA, 2014), which was 1.1 million metric tons higher than its production in 2012/2013 (USDA, 2013). Egypt ranked as the sixth country in global fresh orange production in 2012/2013. Egypt annual production was estimated at 2.450 million tons (USDA, 
2013), and increased in 2013/2014 to 2.570 million tons (USDA, 2014). In Egypt, there are about 85000 tons of fresh orange used for processing juice (USDA, 2013) and produce approximately 51000 ton of fresh citrus pulp (FCP). This massive by-product is not yet extensively used in animal feedstuffs in Egypt and contributes to the environmental pollution. However, drying FCP would be more useful and easier to store and transported to livestock farms. It is estimated that more than 7000 ton of DCP can be produced annually if all FCP is properly dried.

DCP was used at different percentages of substitution with grains (corn, barley, and wheat), dried or pelleted beet pulp, as a part of concentrate feed mixture and sometimes DCP was used as feed supplement to investigate its effect as antioxidant (Castillo et al., 2003; Ahooei et al., 2011; Allam et al., 2011; Santos et al., 2014). Effects of inclusion DCP for dairy cow rations on total antioxidant capacity (TAC) in blood plasma as a type of biomarker of oxidative stress and pathogenic bacteria have not been documented.

The objectives of the study were to evaluate the effect of partial substitution of yellow corn grains by dried orange pulp (DOP) as a type of citrus by-products in ration of Holstein lactating cows, on nutrient digestibility, blood constituents, TAC, Salmonella and E. coli presence in feces.

\section{MATERIALS AND METHODS}

\section{Experimental cows, rations and feeding procedures}

Forty Holstein lactating cows weighing $550 \pm 50 \mathrm{~kg}$, with average of $20 \mathrm{~kg}$ daily milk yield, were randomly distributed into four similar groups. Cows were open housed, and were fed four rations (R1, R2, R3 and R4) with concentrates: roughage ratio of 65:35 on DM basis.

Fresh orange juice by-product containing peel, pulp and seeds were collected from plant of food industry and shipped for drying and produce DOP. The control group (R1) received concentrate feed mixtures (CFM) without
DOP. Cows in groups 2, 3 and 4 were fed CFM contained respectively $25 \%, 50 \%$ and $75 \%$ of DOP as partial substitute with yellow corn grains, respectively (Table I). Corn silage and clover (Trifolium alexandrinum) were used as roughages in balancing the experimental rations.

The concentrates and corn silage were offered together 3 times per day at $5.00 \mathrm{am}, 1.00 \mathrm{pm}$ and $9.00 \mathrm{pm}$ after milking times, and fresh clover (T. alexandrinum) was offered twice daily. Rations were weighed for each group (group feeding). The quantities of daily feed/day/ cow were $16 \mathrm{~kg} \mathrm{CFM}+20 \mathrm{~kg}$ corn silage $+10 \mathrm{~kg}$ clover. Free drinking water was available all the time. The offered feeds were assessed to cover the nutrient requirements for each dairy cow according to NRC (2001).

Table I.- Formulation of the experimental concentrate feed mixtures.

\begin{tabular}{|c|c|c|c|c|}
\hline \multirow[t]{2}{*}{ Ingredients (\%) } & \multicolumn{4}{|c|}{ Concentrate feed mixtures (CFM) } \\
\hline & R1 & $\mathbf{R 2}$ & $\mathbf{R 3}$ & R4 \\
\hline Yellow corn & 40 & 30 & 20 & 10 \\
\hline Dried orange pulp (DOP) & 0 & 10 & 20 & 30 \\
\hline Wheat bran & 15 & 15 & 15 & 15 \\
\hline $\begin{array}{l}\text { Undecorticated } \\
\text { cottonseed meal }\end{array}$ & 15 & 15 & 15 & 15 \\
\hline Lentils & 15 & 15 & 15 & 15 \\
\hline Rice bran & 5 & 5 & 5 & 5 \\
\hline Soybean meal & 5 & 5 & 5 & 5 \\
\hline Limestone & 2 & 2 & 2 & 2 \\
\hline Sodium chloride & 1 & 1 & 1 & 1 \\
\hline Protected fat & 1 & 1 & 1 & 1 \\
\hline Vit. \& Min. Mix.* & 0.5 & 0.5 & 0.5 & 0.5 \\
\hline Sodium bicarbonate & 0.5 & 0.5 & 0.5 & 0.5 \\
\hline Total (\%) & 100 & 100 & 100 & 100 \\
\hline
\end{tabular}

"Each $3 \mathrm{~kg}$ vitamins and minerals mixture contains: Vit. A, $4800000 \mathrm{IU}$; Vit. D3, $1000000 \mathrm{IU}$; Vit. E, $28000 \mathrm{mg}$; zinc, $100000 \mathrm{mg}$; manganese, $80000 \mathrm{mg}$; iron, $75000 \mathrm{mg}$; copper, $30000 \mathrm{mg}$; iodine, $750 \mathrm{mg}$; cobalt, $200 \mathrm{mg}$; silinum, $300 \mathrm{mg}$; calcium bicarbonate, up to $3 \mathrm{~kg}$. R1, control; R2, 25\% DOP; R3, 50\% DOP; R4, 75\% DOP.

Table II.- Culture medium, counting method and growth conditions were used for detection of Escherichia coli and Salmonella spp.

\begin{tabular}{|c|c|c|c|}
\hline $\begin{array}{l}\text { Microbial } \\
\text { group }\end{array}$ & Medium & $\begin{array}{l}\text { Counting } \\
\text { method }\end{array}$ & Incubation conditions \\
\hline \multirow{2}{*}{ Escherichia coli } & EC broth & MPN & $44.5^{\circ} \mathrm{C} / 24-48 \mathrm{~h}$. \\
\hline & L- eosin methylene blue agar & ------- & $37^{\circ} \mathrm{C} / 24 \mathrm{~h}$ \\
\hline \multirow{3}{*}{$\begin{array}{l}\text { Detection of } \\
\text { Salmonella spp. }\end{array}$} & Buffered peptone water for the pre-enrichment step. & ------- & $37^{\circ} \mathrm{C} / 24 \mathrm{~h}$ \\
\hline & $\begin{array}{l}\text { Selenite cystine broth and Rappaport-Vassiliadis medium } \\
\text { for the enrichment step. }\end{array}$ & & $\begin{array}{l}37^{\circ} \mathrm{C} / 24 \mathrm{~h} . \text { for inoculated Selenite cystine } \\
\text { broth and } 42^{\circ} \mathrm{C} / 24 \mathrm{~h} \text { for inoculated } \\
\text { Rappaport-Vassiliadis medium. }\end{array}$ \\
\hline & $\begin{array}{l}\text { Xylose lacose deoxycholate agar and brilliant green agar } \\
\text { as selective medium for isolation of Salmonella spp. }\end{array}$ & & $37^{\circ} \mathrm{C} / 24-48 \mathrm{~h}$ \\
\hline
\end{tabular}

MPN, most probable number. 


\section{Sampling and analysis}

Samples of feed ingredients, concentrates and feces were analyzed for dry matter (DM), organic matter (OM), ether extract (EE), crude protein (CP) and crude fiber (CF) according to the methods of AOAC (2000). Nitrogen free extract (NFE) was calculated by difference. Neutral detergent fiber (NDF), acid detergent fiber (ADF) and acid detergent lignin (ADL) were analyzed by Ankom200 Fiber Analyzer (Ankom Technology Corporation, Fairport, NY, USA) according to van Soest et al. (1991). Cellulose and hemicelluloses percentages were calculated by the difference. Gross energy (GE) were calculated according to Edwards and Allan (2004) equations: GE (MJ/kg DM) $=23.6 * \mathrm{CP}(\mathrm{g})+39.5 * \mathrm{EE}(\mathrm{g})+17.2 *$ carbohydrates $(\mathrm{g})$.

Fecal samples were individually taken from three animals in each group at the end of milk production trial and analyzed on the same day for Salmonella spp. according to ISO 6579 (2002) and E. coli according to FDA (2002). The culture medium, counting method and growth conditions used for each microbial group are showed in Table II.

Blood samples were collected from three animals in each group at the end of the digestion trial. Blood was withdrawn from the subcutaneous abdominal vein in heparinized tubes at $4 \mathrm{~h}$ after morning feeding. Blood hemoglobin $(\mathrm{Hb}, \mathrm{g} / \mathrm{dl})$ was determined by colorimetric method (Spectrophotometer Jenway 6300 U.K) according to Wintrobe (1956), hematocrit $(\mathrm{Ht} \%)$, red blood cells (RBCs), white blood cells (WBCs) and platelets determined by Hemocytometer according to Pushkar and Bhatta (2013).

Blood plasma was obtained by spinning the blood at $5000 \mathrm{rpm}$ for $15 \mathrm{~min}$ in a clean dried glass vial, and stored at $-20^{\circ} \mathrm{C}$ to determine blood plasma constituents. Blood plasma parameters were analyzed calorimetrically using Jenway 6300 Spectrophotometer U.K. Plasma alanine transaminase (ALT) and aspartate transaminase (AST) concentration (RFU/ml) were measured according to Reitman and Frankel (1957), albumin (g/dl) as described by Doumas et al. (1971), creatinine (mg/dl) according to Bartels (1972), total protein (g/dl) as described by Cannon (1974), total lipids $(\mathrm{mg} / \mathrm{dl})$ as described by Eisemann et al. (1986) and urea (mg/dl) as described by Fawcett and Scott (1960). Total antioxidant capacity (TAC) was done by using Stat lab szs160 - Spectrum device according to Koracevicet al. (2001).

\section{Digestion trial}

The digestion trials were conducted at the last week of the experiment according to van Keulen and Young (1977) using acid insoluble ash (AIA) method. Fecal samples were collected from the rectum of 3 animals in each group, at 10.00 am and $4.00 \mathrm{pm}$ for three successive days, and mixed (six samples for each animal) then stored under deep freezing for later analysis.

\section{Statistical analysis}

The obtained data were statistically analyzed using one-way analysis of variance according to XLSTAT (2013) using the following model:

$$
\mathrm{Y}_{\mathrm{ij}}=\mu+\mathrm{T}_{\mathrm{i}}+\mathrm{e}_{\mathrm{ij}}
$$

Where, $Y_{i j}$ is observation, $\mu$ is general mean of treatments, $\mathrm{T}_{\mathrm{i}}$ is effect of treatment and $\mathrm{e}_{\mathrm{ij}}$ is experimental error.

Differences among means were compared by Duncan's multiple range (Duncan, 1955).

\section{RESULTS AND DISCUSSION}

\section{Chemical composition of feed ingredients, CFM and experimental rations}

Dry matter composition and cell wall constituents (\%) of yellow corn, dried orange pulp, roughages feedstuffs and experimental CFM are shown in Table III. Results indicated that DM \%, CP \% contents and GE (MJ/kg DM) of DOP and yellow corn grains are approximately equal. The values of OM, NFE, and hemi-cellulose of DOP were found to be lower than that of yellow corn grains. In contrast, values of CF, EE, NDF, ADF, ADL and cellulose were found to be higher than that of yellow corn grains.

The DM and CP for DOP are in agreement with those reported by Ensminger and Olentine (1978) and NRC (1988). The value of GE for DOP is in agreement with those reported by Bampidis and Robinson (2006). The OM and EE content of DOP are near to that found by NRC (2001) and Allam et al. (2011). The CF results are in an agreement with these reported by Belibasakis and Tsirgogianni (1996). The NFE value for DOP was to that obtained by Hutton (1987) and Caparra et al. (2007). This result for NDF in DOP is in agreement with that of Allam et al. (2011) and close to these reported by Hutton (1987) and Belibasakis and Tsirgogianni (1996). Acid detergent fiber (ADF) for DOP was 4.86 times higher than ADF in yellow corn grains $(23.80 \%$ vs. $4.90 \%)$. While, the ADF of DOP in the present study is higher than those reported by NRC (1988, 2001), Bampidis and Robinson (2006) and Allam et al. (2011) who recorded ADF content of DOP ranging from 16 to $22.2 \%$. Results of ADL from the present study are in agreement with Allam et al. (2011).

The concentrate mixtures (Table III) as well as the experimental ration (Table IV) were isocaloric and isonitrogenous. Roughage to concentrate ratio was on average 34.8: 65.2\% in experimental rations on DM basis. 
Table III.- Chemical composition (on DM basis) and cell wall constituents (\%) of yellow corn, dried orange pulp, roughages feedstuffs and experimental concentrate feed mixtures (CFM).

\begin{tabular}{|c|c|c|c|c|c|c|c|c|}
\hline \multirow[t]{2}{*}{ Items } & \multicolumn{4}{|c|}{ Feed ingredients } & \multicolumn{4}{|c|}{ Concentrate feed mixtures (CFM) } \\
\hline & $\begin{array}{l}\text { Yellow } \\
\text { corn }\end{array}$ & DOP & \begin{tabular}{|c|} 
Corn \\
silage
\end{tabular} & $\begin{array}{c}\text { Egyptian } \\
\text { clover }\end{array}$ & $\begin{array}{c}\text { CFM1 } \\
\text { (Control) }\end{array}$ & $\begin{array}{c}\text { CFM2 } \\
\text { (25\% DOP) } \\
\end{array}$ & $\begin{array}{c}\text { CFM3 } \\
\text { (50\% DOP) } \\
\end{array}$ & $\begin{array}{c}\text { CFM4 } \\
\text { (75\% DOP) }\end{array}$ \\
\hline \multicolumn{9}{|c|}{ Chemical composition, \% (on DM basis) } \\
\hline $\mathrm{DM}$ & 90.41 & 89.66 & 30.65 & 16.72 & 91.49 & 91.42 & 91.34 & 91.27 \\
\hline $\mathrm{OM}^{1}$ & 97.44 & 92.51 & 90.56 & 84.42 & 90.39 & 89.90 & 89.40 & 88.91 \\
\hline $\mathrm{CP}$ & 8.07 & 8.48 & 8.76 & 18.63 & 15.41 & 15.45 & 15.49 & 15.53 \\
\hline $\mathrm{CF}$ & 3.24 & 13.85 & 28.54 & 30.38 & 7.53 & 8.59 & 9.65 & 10.71 \\
\hline $\mathrm{EE}$ & 1.84 & 4.66 & 1.23 & 1.49 & 4.86 & 5.14 & 5.42 & 5.71 \\
\hline ASH & 2.56 & 7.49 & 9.44 & 15.58 & 9.61 & 10.10 & 10.60 & 11.09 \\
\hline $\mathrm{NFE}^{2}$ & 84.29 & 65.51 & 52.04 & 33.92 & 62.59 & 60.71 & 58.84 & 56.96 \\
\hline \multicolumn{9}{|c|}{ Cell wall constituents (\%) } \\
\hline NDF & 23.40 & 26.36 & 68.71 & 53.06 & 31.19 & 31.49 & 31.78 & 32.08 \\
\hline $\mathrm{ADF}$ & 4.90 & 23.80 & 41.14 & 39.25 & 12.20 & 14.09 & 15.98 & 17.87 \\
\hline $\mathrm{ADL}$ & 1.34 & 2.20 & 9.40 & 10.10 & 4.08 & 4.17 & 4.25 & 4.34 \\
\hline Hemicelluloses $^{3}$ & 18.50 & 2.55 & 27.57 & 13.81 & 18.99 & 17.40 & 15.80 & 14.21 \\
\hline Cellulose $^{4}$ & 3.56 & 21.61 & 31.74 & 29.15 & 8.12 & 9.92 & 11.73 & 13.53 \\
\hline $\mathrm{GE}(\mathrm{MJ} / \mathrm{kgDM})^{5}$ & 17.69 & 17.49 & 16.41 & 16.04 & 17.62 & 17.60 & 17.58 & 17.56 \\
\hline
\end{tabular}

DM, dry matter; OM, organic matter; CP, crude protein; CF, crude fiber; EE, ether extract; NFE, nitrogen free extract; NDF, neutral detergent fiber; ADF, acid detergent fiber; ADL, acid detergent lignin; GE, growth energy. ${ }^{1,2,3,4,5}$, calculated.

Table IV.- Formulation of the experimental rations and its DM composition.

\begin{tabular}{lcccc}
\hline Items & \multicolumn{4}{c}{ Experimental rations } \\
\cline { 2 - 5 } & R1 & R2 & R3 & R4 \\
\hline Composition (\%) & & & & \\
CFM & 65.23 & 65.21 & 65.20 & 65.18 \\
Roughage & 34.77 & 34.79 & 34.80 & 34.82 \\
Corn silage & 27.32 & 27.33 & 27.35 & 27.36 \\
Egyptian clover & 7.45 & 7.45 & 7.46 & 7.46 \\
Chemical composition & & & & \\
DM & 91.95 & 91.90 & 91.85 & 91.80 \\
OM & 89.99 & 89.67 & 89.35 & 89.03 \\
CP & 13.83 & 13.86 & 13.88 & 13.91 \\
EE & 3.62 & 3.80 & 3.98 & 4.17 \\
CF & 14.97 & 15.67 & 16.36 & 17.06 \\
NFE & 57.57 & 56.34 & 55.12 & 53.89 \\
Ash & 10.01 & 10.33 & 10.65 & 10.97 \\
Cell wall constituents & & & \\
NDF & 42.04 & 43.27 & 43.47 & 43.67 \\
ADF & 22.12 & 23.36 & 24.60 & 25.83 \\
ADL & 5.98 & 6.04 & 6.10 & 6.15 \\
Hemicelluloses & \\
Cellulose & 19.92 & 19.91 & 18.87 & 17.84 \\
GE (MJ/kg DM) $^{5}$ & 16.14 & 17.32 & 18.50 & 19.68 \\
\hline & 17.17 & 17.16 & 17.14 & 17.13 \\
\hline
\end{tabular}

R1, control; R2, 25\% DOP; R3, 50\% DOP; R4, 75\% DOP. Hemicellulose= NDF - ADF; Cellulose $=$ ADF- ADL; ; $, 2,3,4,5$, calculated. For abbreviations, see Table III.
Effect of partial substitution of yellow corn by DOP

Nutrient digestibility and nutritive value of the experimental rations

Partial substitution of yellow corn grains by different levels of DOP (R2, R3, and GR4) did not affect digestibility of all nutrient except NFE (Table V) compared to control group (R1). These results are in agreement with those of Gholizadeh and Naserian (2010), Ahooei et al. (2011), Allam et al. (2011) and Shdaifat et al. (2013).

The ether extract digestibility (EED) coefficient values increased with increasing level of replacement of yellow corn grains by DOP in the rations, but the differences among treatments were not statistically significant. The reasons of increasing values of EED may be due to increased feed intake of EE by $0.18,0.36$ and $0.55 \%$ in $\mathrm{R} 2, \mathrm{R} 3$ and $\mathrm{R} 4$, respectively (EE intake were increased by $28.8,57.6$ and $88 \mathrm{~g} / \mathrm{cow} / \mathrm{d}$ in R2, R3 and R4, respectively compared to control). Lipids from DCP contain mainly unsaturated fatty acids, which are known to be more digestible than saturated fatty acids. So, the additional amount of digestible EE from DCP may contribute to increase of digestion EE. Also, antioxidants present in DCP could have contributed to increase digestion coefficient of EE (Lima et al., 2014). The experimental rations were isocaloric and isonitrogenous. The nutritive values ranged from 64.16 to $66.89 \%$ for TDN and ranged from 9.15 to $9.86 \%$ for digestible CP. 
Table V.- Effect of partial substitution of yellow corn by dried orange pulp in dairy cow ration on nutrients digestibility and nutritive value of the experimental rations.

\begin{tabular}{lccccc}
\hline \multirow{2}{*}{ Items } & \multicolumn{4}{c}{ Experimental groups } & SEM \\
\cline { 2 - 5 } & $\mathbf{R 1}$ & $\mathbf{R 2}$ & $\mathbf{R 3}$ & $\mathbf{R 4}$ & \\
\hline Digestion coefficient (\%) & & & & \\
DM & 67.13 & 68.66 & 66.03 & 63.79 & 0.96 \\
OM & 69.08 & 70.18 & 67.52 & 66.96 & 0.84 \\
CP & 66.14 & 67.87 & 71.05 & 67.09 & 1.21 \\
CF & 58.62 & 55.21 & 60.00 & 58.26 & 1.27 \\
EE & 83.55 & 82.85 & 87.38 & 89.25 & 1.34 \\
NFE & $71.59^{\text {ab }}$ & $74.05^{\mathrm{a}}$ & $67.41^{\mathrm{b}}$ & $67.95^{\mathrm{ab}}$ & 1.12 \\
NDF & 53.96 & 55.94 & 54.11 & 55.05 & 1.06 \\
ADF & 37.77 & 41.44 & 38.60 & 44.20 & 1.86 \\
Hemicelluloses & 71.94 & 72.94 & 74.34 & 70.77 & 1.72 \\
Cellulose & 55.25 & 57.26 & 56.39 & 56.77 & 1.30 \\
Nutritive values (\% DM basis) & & & \\
TDN & 65.88 & 66.89 & 64.88 & 64.16 & 0.74 \\
Digestible CP & 9.15 & 9.41 & 9.86 & 9.33 & 0.17 \\
\hline
\end{tabular}

a,b, means of treatments within the same row with different superscript letters are significantly different $(\mathrm{P} \leq 0.05)$. DOP, dried orange pulp. For abbreviations, see Table III. R1, control; R2, 25\% DOP; R3, 50\% DOP; R4, 75\% DOP.

\section{In dairy cow rations on blood parameters}

Increasing level of DOP had no significant effect on platelet count, RBCs, Ht (\%), Hb, ALT, AST, Total Protein, albumin, creatinine and urea as shown in Table VI. These results are in agreement with Belibasakis and Tsirgogianni (1996), Allam et al. (2011). In contrast, the values of WBCs, globulin and total lipids $(\mathrm{P} \leq 0.05)$ decreased by increasing the replacement levels of DOP in rations. The results of Total lipids were not in agreement with reported values by Belibasakis and Tsirgogianni (1996), Ahooei et al. (2011), Allam et al. (2011) and Santos et al. (2014).

The value of total antioxidant capacity (TAC) as a biomarker of oxidative stress was gradually increased by increasing level of DOP in experimental rations (ranged from 0.420 to $0.433 \mathrm{~mm} / \mathrm{l}$ ); however, the differences among groups were not significant. More studies are needed to examine the effect of citrus by-products on antioxidant biomarkers especially that TAC in plasma of dairy cow, which is an effective parameter that provides valuable information about the redox conditions of plasma, both dynamically and biologically (Castillo et al., 2006). Also, TAC values are a complementary and necessary tool of great value in assessing the metabolic status and monitor health state of dairy cows (Castillo et al., 2003). Moreover, the future nutritional recommendations for dairy animals will not be based only on energy and protein requirements but may also based on providing antioxidant needs (Castillo et al., 2003).

The partial substitution of yellow corn grains by dried orange pulp in dairy cow ration did not negatively affect animal health and the values of blood parameters of experimental cows, and all values were within normal range.

Table VI.- Effect of partial substitution of yellow corn by dried orange pulp in dairy cow rations on blood analysis.

\begin{tabular}{|c|c|c|c|c|c|}
\hline \multirow[t]{2}{*}{ Items } & \multicolumn{4}{|c|}{ Experimental groups } & \multirow[t]{2}{*}{ SEM } \\
\hline & R1 (Control) & R2 (25\% DOP) & R3 (50\% DOP) & R4 (75\% DOP) & \\
\hline Platelets $(\times 1000)$ & 392.333 & 364.333 & 331.333 & 301.667 & 33.528 \\
\hline WBCs $(\times 1000)$ & $12.500^{\mathrm{a}}$ & $9.733^{\mathrm{ab}}$ & $9.033^{\mathrm{ab}}$ & $8.000^{\mathrm{b}}$ & 1.148 \\
\hline RBCs $(\times 1000000)$ & 6.263 & 6.02 & 5.75 & 5.52 & 0.278 \\
\hline HT $(\%)$ & 30.733 & 30.6 & 32.233 & 32.3 & 2.343 \\
\hline $\mathrm{Hb}(\mathrm{g} / \mathrm{dl})$ & 9.3 & 9.267 & 9.767 & 9.767 & 0.699 \\
\hline ALT (IU/ml) & 11.963 & 12.44 & 12.07 & 12.32 & 0.37 \\
\hline AST (IU/ml) & 16.01 & 22.473 & 21.933 & 21.453 & 4.551 \\
\hline Total Protein (g/dl) & 7.737 & 7.363 & 5.873 & 5.98 & 0.681 \\
\hline Albumin $(\mathrm{g} / \mathrm{dl})$ & 3.19 & 3.823 & 3.273 & 3.117 & 0.235 \\
\hline Globulin (g/dl) & $4.547^{\mathrm{a}}$ & $3.540^{\mathrm{ab}}$ & $2.600^{\mathrm{b}}$ & $2.863^{\mathrm{ab}}$ & 0.559 \\
\hline Total lipids (mg/dl) & $637.703^{\mathrm{a}}$ & $624.590^{\mathrm{a}}$ & $300.547^{\mathrm{b}}$ & $395.630^{\mathrm{b}}$ & 62.504 \\
\hline Creatinine (mg/dl) & 0.927 & 1.15 & 0.877 & 0.937 & 0.095 \\
\hline Urea (mg/dl) & 9.383 & 9.81 & 15.87 & 17.24 & 4.048 \\
\hline Total antioxidant capacity $(\mathrm{mm} / \mathrm{l})$ & 0.420 & 0.423 & 0.430 & 0.433 & 0.028 \\
\hline
\end{tabular}

DOP, dried orange pulp; WBCs, white blood cells; RBCs, red blood cells; Ht, hematocrit; Hb, hemoglobin; ALT, plasma alanine transaminase; AST, aspartate transaminase. ${ }^{\mathrm{a}, \mathrm{b}}$, means of treatments within the same row with different superscript letters are significantly different $(\mathrm{P} \leq 0.05)$. 
On E. coli and Salmonella spp. in feces

Data in Table VII concerning presence of fecal pathogenic bacteria showed that feces of experimental cows fed experimental rations did not contain Salmonella spp. Also, Callaway et al. (2011) studied the effects of feeding up to $20 \%$ DOP to sheep on fecal Salmonella content, but Salmonella was not detected and this because sheep did not consume more than $10 \%$ DOP diet, likely due to palatability concerns. However, feeding $10 \%$ DOP in the ration reduced rune all, cecal and rectal populations of Salmonella typhimurium approximately 1,2 and $0.5 \log ^{10}$ CFU $(\mathrm{P}<0.08,<0.06,<0.10)$, respectively (Callaway et al., 2011).

Data in Table VII showed that cows fed experimental rations did not have significant effect in reducing fecal count of $E$. coli bacteria. The result was surprising because all groups have the same number of $E$. coli. These results are not in agreement with those found by Nam et al. (2006), Kirbaşlar et al. (2009), Callaway et al. (2011), Allam et al. (2011), Okunowo et al. (2013) and Lee et al. (2014) who reported that citrus essential oils reduced $E$. coli.

Table VII.- Effect of partial substitution of yellow corn by dried orange pulp in dairy cow rations on $E$. coli and Salmonella spp. in feces of dairy cow.

\begin{tabular}{lcc}
\hline Experimental groups & E. coli $($ MPN/g) & Salmonella spp. \\
\hline R1 (Control) & $1.4 \times 10^{3}$ & Not detected \\
R2 $(25 \%$ DOP) & $1.4 \times 10^{3}$ & Not detected \\
R3 $(50 \%$ DOP) & $1.4 \times 10^{3}$ & Not detected \\
R4 (75\% DOP) & $1.4 \times 10^{3}$ & Not detected \\
\hline
\end{tabular}

MPN, most probable number; DOP, dried orange pulp.

\section{CONCLUSION}

It may be concluded that DOP can replace up to $75 \%$ of yellow corn grains in Holstein dairy cow's rations without negatively effecting nutrient digestibility, nutritive values, and blood parameters. Further studies are needed to study the effect of feeding DOP to lactating cows on presence and count of fecal Salmonella and E. coli in feces, and level of antioxidant biomarkers in milk and blood.

\section{ACKNOWLEDGEMENT}

Deep thanks to Dr. Rida Ali for his valuable advice and assistance and to Dr. Abd El-Rauf Algohary for his support in providing animals and feeding facilities used during the entire study period.

\section{Statement of conflict of interest}

The authors declare no conflict of interest.

\section{REFERENCES}

Ahooei, G.R., Foroughi, A.R., Tahmasbi, A.M., Shahdadi, A.R. and Vakili, R., 2011. Effects of different levels of dried citrus pulp and urea on performance of fattening male calves. J. Anim. Vet. Adv., 10: 1811-1816. https://doi.org/10.3923/ javaa.2011.1811.1816

Allam, S.M., Abou-Ward, G.A., Tawila, M.A., Ali, M.A., Al-Hosseiny H.M., Sayed, S.K. and ElNaggar, S.I., 2011. Nutritional and economical impact of using dried orange pulp as energy source in growing lambs rations. Egyptian J. Nutri. Feeds, 14: 337-347.

Ammerman, C.B. and Henry, P.R., 1991. Citrus and vegetable products for ruminant animals. Proceedings of the Alternative Feeds for Dairy and Beef Cattle Symposium 1991, Columbia, pp.103110.

AOAC, 2000. Official methods of analysis, $14^{\text {th }}$ ed. Published by the Association of Official Analytical Chemists, Washington, DC, USA, pp. 684.

Bampidis, V.A. and Robinson, P.H., 2006. Citrus by-products as ruminant feeds: A review. Anim. Feed Sci. Technol., 128: 175-217. https://doi. org/10.1016/j.anifeedsci.2005.12.002

Bartels, H., 1972. Serum creatinine without interference. Clin. Chem. Acta, 37: 193-197. https://doi. org/10.1016/0009-8981(72)90432-9

Belibasakis, N.G. and Tsirgogianni, D., 1996. Effects of dried citrus pulp on milk yield, milk composition and blood components of dairy cows. Anim. Feed Sci. Technol., 60: 87-92. https://doi.org/10.1016/03778401(95)00927-2

Callaway, T., Carroll, J.A., Arthington J.D., Edrington T.S., Rossman, M.L., Carr, M.A., Krueger, N.A., Ricke, S.C., Crandall, P. and Nisbet, D.J., 2011. Escherichia coli $\mathrm{O} 157: \mathrm{H} 7$ populations in ruminants can be reduced by orange peel product feeding. J. Fd. Protec., 74: 1917-1921. https://doi. org/10.4315/0362-028X.JFP-11-234

Cannon, D.C., 1974. Clinical chemistry-principles and techniques (ed. R.J. Henry), $2^{\text {nd }}$ ed. Harper and Row, Hagerstown, MD, pp. 411-421.

Caparra, P., Foti, F., Scerra, M., Sinatra, M.C. and Scerra, V., 2007. Solar-dried citrus pulp as an alternative energy source in lamb diets: Effects on growth and carcass and meat quality. Small Rumin. Res., 68: 303-311. https://doi.org/10.1016/j. smallrumres.2005.11.015

Castillo, C., Hernandez, J., López-alonso, M., Miranda, M. and Benedito, J.L., 2003. Values of plasma 
lipid hydroperoxides and total antioxidant status in healthy dairy cows: preliminary observations. Arch. Tierz. Dummerstorf., 46: 227-233. https:// doi.org/10.5194/aab-46-227-2003

Castillo, C., Hernandez, J., Valverde, I., Pereira, V., Sotillo, J., Alonso, M.L. and Benedito, J.L., 2006. Plasma malonaldehyde (MDA) and total antioxidant status (TAS) during lactation in dairy cows. Res. Vet. Sci., 80: 133-139. https://doi. org/10.1016/j.rvsc.2005.06.003

Doumas, B.T., Waston, W. and Biggs, H.G., 1971. Albumin standards and the measurement of serum albumin with bromcresolgreen. Clin. Chim. Acta, 31: 87-96. https://doi.org/10.1016/00098981(71)90365-2

Duncan, D.B., 1955. Multiple range and multiple F-test. Biometrics, 11: 1-42. https://doi. org/10.2307/3001478

Edwards, P. and Allan, G.L., 2004. Feeds and feeding for inland aquaculture in Mekong region countries. ACIAR Tech. Rep., 56: 136.

Eisemann, J.H., Hammond, A.C., Bauman, D.E., Renolds, P.J., Ma Culchoen, S.N., Tyrrel, H.F. and Haaland, G.L., 1986. Heifers protein and lipid metabolism and plasma concentration of metabolites and hormones. J. Nutri., 116: 25042515. https://doi.org/10.1093/jn/116.12.2504

Ensminger, M.E. and Olentine, C.G., 1978. Feeds and nutrition, $1^{\text {st }}$ ed. The Ensminger Publishing Company, Clovis, CA, USA.

Fawcett, J.K. and Scott, J.E., 1960. A rapid and precise method for the determination of urea. $J$. clin. Pathol., 13: 156. https://doi.org/10.1136/ jcp.13.2.156

FDA, 2002. BAM 4: Enumeration of Escherichia coli and the coliform bacteria. Food and Drug Administration, USA. Available at: http:// www.fda.gov/Food/FoodScienceResearch/ LaboratoryMethods/ucm064948.htm (Accessed on 27 March, 2019).

Gholizadeh, H. and Naserian, A.A., 2010. The effects of replacing dried citrus pulp with barley grain on the performance of Iranian Saanen kids. J. Anim. Vet. Adv., 9: 2053-2056. https://doi.org/10.3923/ javaa.2010.2053.2056

Harris, B., 1991. Value of high-fiber alternative feedstuffs as extenders of roughage sources. Proceedings of the Alternative Feeds for Dairy and Beef Cattle Symposium 1991, Columbia, pp. 138.

Hutton, K., 1987. Citrus pulp in formulated diets. In: Recent advances in animal nutrition proceedings. Department of Industry, Innovation and Science,
Australia. Available at: http://livestocklibrary.com. au/handle/1234/19532 (Accessed on 27 March, 2019).

ISO 6579, 2002. Microbiology of food and animal feeding stuffs - Horizontal method for the detection of Salmonella spp. International Organization for Standardization, Geneva, Switzerland, pp. 1-7.

Kirbaşlar, F.G., Tavman, A., Dülger, B. and Türker, G., 2009. Antimicrobial activity of Turkish citrus peel oils. Pak. J. Bot., 41: 3207-3212.

Koracevic, D., Koracevic, G., Djordjevic, V., Andrejevic, S. and Cosic, V., 2001. Method for the measurement of antioxidant activity in human fluids. J. clin. Pathol., 54: 356-361. https://doi. org/10.1136/jcp.54.5.356

Lee, J.H., Cho, S., Paik, H.D., Choi, C.W., Nam, K.T., Hwang, S.G. and Kim, S.K., 2014. Investigation on antibacterial and antioxidant activities, phenolic and flavonoid contents of some Thai edible plants as an alternative for antibiotics. Asian-Australas. $J$. Anim. Sci., 27: 1461-1468. https://doi.org/10.5713/ ajas.2013.13629

Lima, L.S., Santos, G.T., Schogor, A.B., Damasceno, J.C., Marchi, F.E., Santos, N.W., Santos, F.S. and Petit, H.V., 2014. Effect of abomasal or ruminal supplementation of citrus pulp and soybean oil on nutrient digestibility and ruminal fermentation of dairy cows. Anim. Feed Sci. Technol., 189: 123-129. https://doi.org/10.1016/j.anifeedsci.2013.12.008

Nam, I.S., Garnsworthy, P.C. and Ahn, J.H., 2006. Supplementation of essential oil extracted from citrus peel to animal feeds decreases microbial activity and aflatoxin contamination without disrupting in vitro ruminal fermentation. AsianAustralas. J. Anim. Sci., 19: 1617-1622. https://doi. org/10.5713/ajas.2006.1617

NRC, 1988. Nutrient requirements of dairy cattle, $6^{\text {th }}$ rev. ed. National Academy Press, Washington, DC, USA.

NRC, 2001. Nutrient requirements of dairy cattle, $7^{\text {th }}$ rev. ed. National Academy Press, Washington, DC, USA.

Okunowo, W.O., Oyedeji, O., Afolabi, L.O. and Matanmi, E., 2013. Essential oil of grape fruit (Citrus paradisi) peels and its antimicrobial activities. Am. J. Pl. Sci., 4: 1-9.

Pushkar, P. and Bhatta, R., 2013. Determination of blood metabolites in cross HF cattle at pre-parturient stage: reference value. Int. J. Pharm. Med. Biol. Sci., 2: 54-57.

Reagan, W.M. and Meade, S.W., 1927. The value of orange pulp for milk production. 
California agric. Exp. Stat. Bull., 427: 1-16. Available at: https://babel.hathitrust.org/cgi/ pt?id=mdp.39015073290549; view=1 up;seq=255 (Accessed on 27 March, 2019).

Reitman, A. and Frankel, S., 1957. A colorimetric method for the determination of serum glutamic oxalacetic and glutamic pyruvic transaminases. Am. J. clin. Pathol., 28: 56-63. https://doi.org/10.1093/ ajcp/28.1.56

Santos, G.T., Lima, L.S., Schogor, A.L.B., Romero, J.V., de Marchi, F.E., Grande, P.A., Santos, N.W., Santos F.S. and Kazama, R., 2014. Citrus pulp as a dietary source of antioxidants for lactating holstein cows fed highly polyunsaturated fatty acid diets. AsianAustralas. J. Anim. Sci., 27: 1104-1113. https://doi. org/10.5713/ajas.2013.13836

Shdaifat, M.M., Al-Barakah, F.S., Kanana, A.Q. and Obeidatb, B.S., 2013. The effect of feeding agricultural by-products on performance of lactating Awassi ewes. Small Rumin. Res., 113: 11-14. https://doi.org/10.1016/j.smallrumres.2013.01.014

USDA, 2013. Citrus: World markets and trade. United States Department of Agriculture. Available at: https://downloads.usda.library.cornell.edu/usdaesmis/files/w66343603/rj430489x/f4752h16g/ citruswm-01-24-2013.pdf

USDA, 2014. Citrus: World markets and trade. United States Department of Agriculture. Available at: https://downloads.usda.library.cornell.edu/usdaesmis/files/w66343603/5q47rp24h/4m90dv93j/ citruswm-07-24-2014.pdf

van Keulen, J.V. and Young, B.A., 1977. Evaluation of acid insoluble ash as a natural marker in ruminant digestibility studies. J. Anim. Sci., 44: 282. https:// doi.org/10.2527/jas1977.442282x

van Soest, P.J., Robertson, J.B. and Lewis, B.A., 1991. Methods for dietary fiber, neutral detergent fiber, and non-starch polysaccharides in relation to animal nutrition. J. Dairy Sci., 74: 3583-3597. https://doi. org/10.3168/jds.S0022-0302(91)78551-2

Wintrobe, M.M., 1956. Clinical hematology, $4^{\text {th }}$ ed. Lea and Fibger, Philadelphia, USA, pp. 1148.

XLSTAT, 2013. Statistical software for MS Excelstatistical and data analysis with MS Excel. Addinsoft, 224 Center Street, 3rd Floor, Second York, NY 10013, USA. 